\title{
THE EFFECT OF MOBILE PROMOTIONS AND APPLICATION QUALITY ON CONSUMERS' MOBILE BUYING IMPULSIVENESS: A CASE OF COMPARISON BETWEEN ZUBIZU AND HOPI
}

\author{
MOBİL PROMOSYONLARIN VE MOBİL UYGULAMA KALİTESININN \\ TÜKETICILLERINN MOBIL ANLIK SATIN ALMA DAVRANIŞI ÜZERINNE ETKİSİ: \\ ZUBİZU VE HOPİ KARŞILAŞTIRMASI ÖRNEĞİ
}

\author{
Yusuf Ozan YILDIRIM* ${ }^{*}$ \\ Azra BAYRAKTAR ${ }^{* *}$ iD
}

\begin{abstract}
Today, digital consumers have adapted to the new world order and started to live their second life in mobile phones. Because everything has centralized over the mobile phones, marketing activities turned their face to the mobile marketing. Shopping activities of consumers moved to the mobile phones, therefore marketing promotions started to be mobile. This paper tries to surface the usage of mobile promotions and its effect on buying impulsiveness. In this research, the effect of sales promotions that appeal to both hedonic and utilitarian consumers and mobile application quality on consumers' mobile buying impulsiveness is examined. In order to achieve this research objective, over many mobile applications which represents both hedonic and utilitarian consumers in Turkey, two commonly used applications are selected. In the results of the research, it was seen that impulsive buying behavior is extracted as two-dimensions; impulsive and suggestion based. According to the results, mobile promotions positively affect both impulsive and suggestion based buying, and the effect on impulsive buying is higher than suggestion based. On the other hand, although the application quality has no effect on impulsive purchasing, it has a positive effect on suggestion based buying behavior. Finally, in order to examine the regression differences between the selected applications, Hopi for utilitarian consumers, and Zubizu for hedonic consumers, research model were examined through structural equation model. According to this; as for the Zubizu application, application quality has more effect on impulsive buying behavior, and for the Hopi
\end{abstract}

* Dicle University, Business Admisitration, yoyildirim@gmail.com, ORCID: 0000-0002-0346-2660

** Marmara University, Business Admisitration, azrbayraktar@gmail.com, ORCID: 0000-0001-8215-6110 
application, mobile promotions are more effective on impulsive buying. As a result, the application for hedonic consumption, impulsiveness acts according to the recommendations. On the other hand, the application for utilitarian consumptions are affected more in a manner of promotional activities.

Keywords: Mobile Promotions, Mobile Application Quality, Mobile Buying Impulsiveness

\section{Öz}

Günümüzde dijital tüketiciler yenidünya düzenine uyum sağlamış ve ikinci hayatlarını cep telefonlarında yaşamaya başlamıştır. Her şey cep telefonları üzerinde merkezileştiği için, pazarlama faaliyetleri yüzünü mobil pazarlamaya çevirmiştir. Tüketicilerin alışveriş faaliyetleri cep telefonlarına taşınmış, bu nedenle pazarlama promosyonları mobil olmaya başlamıştır. Bu makale, mobil promosyonların kullanımının anlık satın alma davranışı üzerindeki etkilerini ortaya çıkarmaya çalışmaktadır. Bu araştırmada, mobil uygulamalardaki hem hazcı hem de faydacı tüketicilere hitap eden satış promosyonlarının ve mobil uygulama kalitesinin, tüketicilerin mobil anlık satın alma davranışına etkisi incelenmiştir. Araştırma amacına ulaşmak için Türkiye'de kullanılan mobil promosyon uygulamaları arasında faydacı ve hazcı tüketicileri ayrı ayrı temsil edebilecek iki yaygın kullanılan uygulama seçilmiştir. Araştırma sonuçlarında anlık satın alma davranışı dürtüsel ve öneri bazlı olarak iki boyutlu olduğu görülmüştür. Mobil promosyonların anlık satın alma boyutlarından ikisini de olumlu yönde etkilerken, dürtüsel satın almayı daha fazla etkilediği incelenmiştir. Öte yandan uygulama kalitesi ise dürtüsel satın alma üzerinde etkisi saptanmamış olmasına rağmen öneri bazlı satın alma davranışı üzerinde etkisi olduğu gözlemlenmiştir. Son olarak, seçilen uygulamalardan faydacı tüketicilere yönelik olan Hopi ve hazcı tüketicilere yönelik olan Zubizu arasındaki farkların incelenmesi için araştırma modeli yapısal eşitlik modeli üzerinden regresyon farkları incelenmiştir. Buna göre; Zubizu uygulaması için anlık satın alma davranışına uygulama kalitesi daha fazla etki ederken, Hopi uygulamasında mobil promosyonların daha etkili olduğu sonucu ortaya çıkmıştır. Sonuç olarak, hedonik tüketime yönelik geliştirilen mobil uygulamalarda tüketicilerin uygulamaların önerilerine göre hareket ettiği görülürken, öte yandan faydacı tüketime odaklı uygulamalarda tüketicilerin promosyonlara odaklı olduğu gözlemlenmiştir.

Anahtar Kelimeler: Mobil Promosyonlar, Mobil Uygulama Kalitesi, Mobil Anlık Satın Alma Davranışı

\section{Introduction}

Nowadays with the help of integration among internet and marketing, some traditional behavior of customers turning into digital. In year 1995, Rook \& Fisher tried to explain customer's behavior of impulsiveness and after this research customer are believed to act impulsive in traditional shopping (Rook \& Fisher, 1995). On the other hand, many years after this work, research scope of impulsiveness extended from traditional to online shopping (Zhou, Dai \& Zhang, 2007).

With the fusion of internet and mobile devices, people started to access internet through mobile devices. This increase in mobile internet usage, converted the way of customers' online purchase to mobile purchase. This way, the growing importance of mobile shopping increases the attention of impulsive shopping through mobile devices. Customers uses applications through mobile devices for shopping and can be impulsive as if they experiencing in-store shopping. As a result, after customers 
turn their way of shopping behavior traditional to online and online to mobile, the impulsive behavior of customers also turns into mobile impulsive behavior of customers.

Recently, developments such as; internet of things and sharing of information, emerged a new situation called collaboration of companies. This collaboration has started a new era for everything (Rifkin, 2014). Most of the companies are now creating mobile applications for their customers but they do not provide their applications under company's name. Instead these providers become a collaborator and presents their applications through another firm's application store. These kind of collaborators are called as third party application providers. On the other hand, the platform/store providers gather information and represents to the third parties. Example of this kind of stores are; Google's play store, Apple's appstore etc. In the end with these collaborations these platforms and applications creates value for the customers and this value enhances customers' change of behaviors.

In conclusion, change in customer's behavior and adaptation of impulsiveness toward mobile created a unique interest for creating a research in this area. In this way, this research consists of two parts. First, the explanation of the theoretical background about impulsiveness, changing internet behavior towards mobile, mobile applications and mobile promotions is explained. After literature review, second part of this research is applied the research model for Turkey's two important applications one is the "zubizu" for hedonic consumption and the other is "hopi" for utilitarian.

\section{Theoretical Framework}

\subsection{Buying Impulsiveness}

The increasing importance of mobile shopping, creating a sharper need understanding of impulse buying on the mobile devices and also becoming increasingly necessary with the help of stimulus offered by mobile applications. Indeed, the existence of mobile features can also stimulate online impulse purchases (Floh \& Madlberger, 2013, p.427).

Buying impulsiveness can be defined as a consumer's tendency to buy unplanned, unreflectively and immediately. In short, buying impulsiveness can effect buyers to act on whim and to respond immediately to their buying impulses (Rook \& Fisher, 1995, p.306) In addition, it's claimed that impulse buying is can be driven by emotions and does not lead to the formation of cognitive intentions (Verhagen \& Van Dolen, 2011, p.321).

In conclusion, buying impulsiveness has been defined as "unplanned buying, result of exposure to a stimulus, instant decision making". The common link of across different definitions of impulse purchases is the unplanned nature of the behavior. Thus, in a mobile context, even purchasing a product based on a provided recommendation from other consumers can be considered an impulse purchase (Parboteeah, Valacich, \& Wells, 2009, p.61). Researches indicate that, it takes 15 seconds for 
customers to decide whether to buy impulsive or not. Also nearly $80 \%$ of all purchases can be impulsive (Hail, et al., 2016).

\subsection{Mobile Buying Impulsiveness}

Developing internet has an important role in daily life. Comparing the retail sales, online sales are growing four times faster with the help of internet penetration through mobile devices (Shankar \& Balasubramanian, 2009). Customers who uses mobile devices for shopping, usually don't make shopping list and instead they focus for offers or discounts (Scarpi, 2012). This behavior naturally leads a perspective in which customers who use mobile devices to shop, may usually not control their natural behaviors to visit online stores. Rather interests in different psychological issues of unplanned and sudden behaviors. In usage of mobile devices when this unplanned and sudden behaviors of customers occurs, it can be referred to as mobile buying impulsiveness (Akram, et al., 2018).

Since the beginning of electronic commerce, marketers investigate the process of mobile shopping and its applications. In this first section literature review, in order to understand the process of usage of mobile devices and buying impulsiveness, first the transition from traditional to online and then to the mobile shopping explained then buying impulsiveness will be dealt extensively.

\subsubsection{Traditional to Online Buying}

In early 1990s, the number of products bought by consumers on the internet has increased. That synergy has caused the transformation process of traditional shopping into online. Thus, researches and studies on the priorities of consumer acceptance of online shopping have attracted widespread attention. On the other hand, attracting and retaining consumers' attention has become a critical issue for the success of online retailers (Zhou, Dai, \& Zhang, 2007, p.41). Internet aggressively grew the potential usage through the past two decades. In December 1995, number of internet users was 16 million, $0.4 \%$ of whole world population. When it comes to end of June 2019 , these number have tremendously changed. Number of internet users raised to 4,5 billion, $58.8 \%$ of world population, in other way one in every two person uses internet (Internet World Stats, 2019).

Growing importance of the internet during the past two decades, changed the perspectives of consumers. Consumers has started to see the internet as a tool for entertainment, communication and market exchange (Miyazaki \& Fernandez, 2001, p.27). In conclusion of this change in perspective, the potential impact of online shopping in the retail industry has become considerably noticeable. This transformation process from traditional to online have benefitted the consumers in ways of collecting price information with little effort, review at a low cost quality-related information and saving time etc (Alba, et al., 1997, p.46). Another thing is, similar to traditional shopping, online stores have atmospheric designs (e.g., graphics, layout, colors) that can impose buying and influence shoppers (Eroglu, Machleit \& Davis, 2003, p.141). Besides that, online shopping requires interaction with a computer, usually in a fixed place, and can easily search various options. Despite the fact that, 
online shopping has many advantages, traditional shopping has also certain niches for certain types of consumer (Ward, 2001, p.105).

The number of online shopping has been rising since the early 2000s. This rapid change of traditional shopping behavior also changed the consumers' habits (Wolfinbarger \& Gilly, 2001, p.34). Thus the marketing researchers have focused on the distinctions between traditional marketing and online marketing (Ward, 2001, p.103). In conclusion, it is assumed that the consumers started to use online shopping over the traditional. Thus consumer behavior in an online shopping environment has largely changed over the time (Haubl \& Trifts, 2000, p.5)

In order to give an example of this change from traditional to online, Alibaba started an online shopping festival in year 2009 with only 27 online merchants. As years passed this event become the world's largest shopping festival with participation of over 1 million stores form different merchants (Business Wire, 2017). In the end of 2019, record of 2016 (shown in Figure1) is multiplied by double (Forbes, 2019).

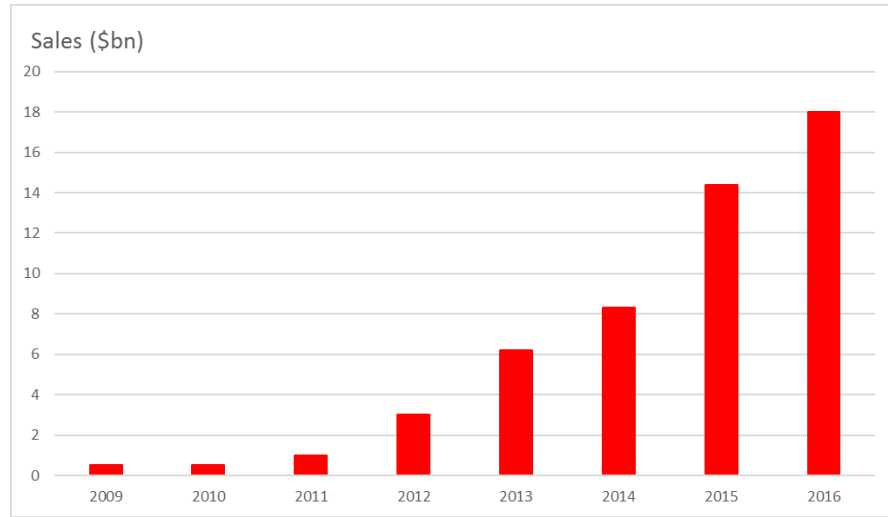

Figure 1. Number of Sales in Alibaba's 11.11 Shopping Festival Through Years

Source: BBC News Services, 2017.

\subsubsection{Online to Mobile Buying}

Within last decade, the growing potential in the use of mobile internet advantaged by always reachable, easy to use, cheaper etc. has resulted in a unique growth in mobile commercials ( $\mathrm{Lu} \& \mathrm{Su}$, 2009, p.442). After the internet has provided prerequisites for electronic commercials and accessible internet from mobile phones, emergence of mobile commercial era has begun. This transaction from online to mobile commerce resulted in the emergence of developing new applications and services to meet customer needs (Agrebi \& Jallais, 2015, p.16).

As the use of wireless technology provided mobile devices and mobile internet to improve, mobile commerce facilitated transactions, information search and user task performance in all sorts 
of communications. Also the potential of mobile internet usage rises against desktop (Statcounter, 2016). Thus the growth of mobile commerce around the world became an important issue. Therefore, understanding the process of online to mobile transformation of consumer behavior became essential for the success of developments in mobile shopping (Hung, Yang \& Hsieh, 2012, p.30).

In addition, what is needed is a much better understanding of the factors that influence the adoption of mobile shopping and clear understanding of the motivations and circumstances from the perception of consumers themselves in mobile shopping ( $\mathrm{Lu} \& \mathrm{Su}, 2009$, p.443).

The growth of mobile services is depended on the enlargement and development of technologies. These technologies include network technologies, service technologies, mobile technologies, mobile commerce terminals, mobile location technologies, mobile promotions, mobile customizations (Siau \& Shen, 2003, p.5). For example, of this new technologies, Starbucks created a "chatbot" allowing customers to request their orders directly verbal to mobile phones. This digital barista also confirms payment and dispatches the order to the nearest store (Apple Insider, 2017).

Although mobile shopping still occupies a small part of all electronic commerce sales, the sophistication of mobile shopping services supported by widespread mobile technologies (Yang, 2012, p.484). Consumers use the mobile applications for a variety of activities, promotions and easiness comparing to shopping in the retails. Also these activities include shopping list, search for the right products and prices in no time, search for retailers, comparing different products, purchasing items etc. (Shankar, et al., 2010, p.113).

\subsection{Mobile Promotions in Mobile Applications}

Importance of mobile promotions for marketers reached the level never before seen. As more people use mobile applications, marketers can reach so many people with the help of mobile applications at almost instantly. Mobile promotions consists of information that is delivered on a mobile device and offers a value in a specific time. This definition of mobile promotions, also referred to as mobile coupons (Andrews, et al., 2016, p.15). Mobile coupon usage through the application is also on the rise. Consumers are using applications through smartphones to view digital coupons or promotions (Forrester Research Inc, 2014). Because 32\% of customers prefer digital coupons via their mobile phones and 70\% of them also check their mobile devices for offers (Carter, 2017).

Mobile commerce is becoming a research area of growing interest, and adoption process of mobile promotion application technologies among consumers. In spite of the great interest in mobile promotions, there is a lack of research on mobile applications that serves mobile promotions (Fang, et al., 2015, p.553). Earlier, researches on sales promotions has attracted the focus of researchers in various ways. However, in this digital era the focus on mobile promotions is growing slowly among researchers. As a result, most analytic and econometric models of mobile promotions can adopt in traditional way of monetary purposes and nonmonetary purposes. Use intention of monetary purposes are for hedonists and nonmonetary for utilitarian (Chandon, Wansink \& Laurent, 2000, 
p.66). Marketers can use this benefit framework of mobile promotions to separation of utilitarian promotions and hedonic promotions and can select appropriate promotions for applications (Liao, Shen \& Chu, 2009, p.252).

Mobile promotions are divided into two categories. Which are monetary promotions (adjusted toward price) and non-monetary promotions (promotions that does not directly involve the price of the product). Non-monetary promotions mostly include of free samples, prizes, contests, loyalty or rewards (Boschetti, et al., 2017, p.4).

\subsubsection{Non-Monetary (Hedonic)}

Non-monetary promotions are becoming important in mobile promotional activities. Non-monetary mobile promotions may help to create differentiated brands, distinctive communication and improved brand equity (Buil, De Chernatony \& Martinez, 2013, p.118) Non-monetary promotions are distinctive in perceptions by consumers than monetary promotions. Non-monetary promotions sometimes can be limited with premium choices (Campbell \& Diamond, 1990, p.28).

As an example of non-monetary promotions in mobile devices, $P \& G$ has started a special highlighted movement in Turkey which is called "BanaBak". BanaBak is a special young movement mostly relied on digital content production. After a while, $P \& G$ transforms the BanaBak movement into a mobile application. Also in this mobile application $P \& G$ tried to appeal the young people by combining receipt reading technology and gamification. Thus, the company has taken advantage of the loyalty application with an enjoyable approach and has increased its usage rate (Webrazzi, 2018)

Non-monetary mobile promotions are closely related to hedonic benefits, emotional behavior, pleasure and self-esteem (Palazn-Vidal \& Delgado-Ballester, 2005, p.182). For example; advertised items, free samples, free goods, premium tryouts and etc (Köksal, 2014). Non-monetary mobile promotions of hedonic order consists of 3 variables which are value expression, exploration and entertainment (Chandon, Wansink \& Laurent, 2000)

\subsubsection{Monetary (Utilitarian)}

Most of the previous researches on promotions focus on monetary reasons. In mobile promotions, there are some discussion about the effect of this tool of monetary promotions. Thus, focusing on the direct effects of monetary promotions is associated as an important issue (Buil, De Chernatony \& Martinez, 2013, p.117). Because of this growing importance inspired most of researchers to conduct on mobile promotions. With the help of earlier studies in which most of them have examined the convenience of promotions and benefits for customers, it is presumed that mobile promotions for monetary savings are beneficial to work for (Palazn-Vidal \& Delgado-Ballester, 2005, p.181).

In most of monetary promotions the value of product is often explicit, so it is comparably easy for consumers to value from promotions. Therefore, it is easier for consumers to integrate discounts 
with price. Hence, it's expected to consumers to be a part of the discount process (Chandran \& Morwitz, 2006, p.385). Unlike non-monetary promotions, monetary promotions are about benefits of behavioral goals (Campbell \& Diamond, 1990, p.28). Mostly known examples of monetary promotions is coupons, discounts, price promotions, in-store promotions and etc (Köksal, 2014). Therefore, monetary mobile promotions of utilitarian order consist of 3 variables which are savings, quality and convenience (Chandon, Wansink \& Laurent, 2000).

\subsection{Scales for Application Quality}

Today most mobile service providers for applications (e.g. Android Market, App Store) maintains users to search by keywords and rate applications made by third party developers. In this section, as first we discussed the impulsiveness, transition to mobile, promotions and now the applications' quality in which provides promotion to invoke impulsiveness will be explained. In the literature there are two kind of quality based scales. One is mobile application rating scale, and the other one is application quality scale (is adopted form of webqual from (Wells, Parboteeah \& Valacich, 2011).

Mobile applications share in market are rapidly growing these years (approximate number of applications in millions: Google Play, 2.8m, Apple Store, 2.2m, Windows Store, 0.7, Amazon App Store, 0.6 and BlackBerry World 0.2 (Statista, 2017). While the application stores allow the users to search for applications by keywords or browse top applications in different categories, quality of applications are equally important. Most of application developers are aware of the importance of application quality and its ratings from users (Yan \& Chen, 2011, p.113). With given information, the following chapters will explain the ratings of mobile applications and the importance of mobile applications quality.

\subsubsection{Mobile Application Rating Scale}

Mobile internet usage gets higher portion in everyday and companions reaching the attention of research in mobile applications. The improvements of the hardware related to mobile technologies enhances the capabilities of various applications. In order to prioritize the works of application developers, publishers of applications centralizes a scale in which consumer can directly rate the applications with their mobile devices (Girardello \& Michahelles, 2010, p.606). In short, consumers first use the application and then rate the application within given ratio (e.g. 0/5). After the rating is done, other users can see the rating and make comment about the application.

In the online world, mobile devices usage is growing rapidly. Especially among young people particularly (Mani, et al., 2015). Given the rapid growth of mobile devices applications, it is increasingly difficult for users, to identify and assess the quality of applications. In actual the rate of an applications reflects the basis of popularity or meaningful information about application (Stoyanov, et al., 2015) 
In conclusion the Mobile App Rating Scale (MARS) can provide researchers with a brief tool for classifying and assessing the quality of applications. MARS contains 4 variables which are engagement, functionality, aesthetics, and information quality (Stoyanov, et al., 2016)

\subsubsection{Application Quality Scale}

In the traditional shopping, marketers manipulate the atmospheric cues in retail environment to trigger impulse purchases (Rook \& Fisher, 1995, p.306). Similarly, in an online context, researchers have examined the online environment that can trigger impulse purchases. These environmental cues often occur as in various characteristics that influence impulsiveness of consumers (Loiacono, Watson \& Goodhue, 2007, p.55). In this digital age same characteristics of a website quality that arouses impulsive behaviors can be adopted to the mobile applications.

During the past decades, researchers have largely focused on information systems for productivity, competitiveness enhancement in online world and quality of websites (Lee \& Kozar, 2006, p.1384). The supposition in these studies origins from a company's website is a key tool for communication and is the primary interface customers in all cases (Kim \& Stoel, 2004, p.110). Web site usability can reflect the quality of a firm's Web presence. Therefore, a measure of quality must illuminate specific strengths and weaknesses associated with site design (Agarwal \& Venkatesh, 2002, p.168). In this research, all of these specific details are converted into to mobile and adopted in order to measure an application's quality.

Mobile applications that provides environmental details at a high level also offers an online interface in the meaning of quality. High quality mobile cues can influence online impulse buying (Parboteeah, Valacich, \& Wells, 2009). In addition, application quality interplays a role between an online consumer's impulsiveness and high quality mobile applications (Eroglu, Machleit \& Davis, 2001, p.180). To summarize, applications success can come from the quality and has become the focus of great interest and attention (Loiacono, Chen \& Goodhue, 2002).

Table 1. Application Quality in Detail

\begin{tabular}{|c|c|c|}
\hline \multicolumn{3}{|c|}{ Application quality by Wells and Parboteeah. 2011} \\
\hline Dimensions & Characteristics & Items \\
\hline Security & Structural Firmness & $\begin{array}{ll}\text { - } & \text { Personal Information Privacy } \\
\text { - } & \text { Not Sharing Personal Information } \\
\text { - } & \text { Not Storing Personal Information }\end{array}$ \\
\hline Navigability & Functional Convenience & $\begin{array}{ll}\text { - } & \text { Easy to Navigate } \\
\text { - } & \text { Clear to Understand } \\
\text { - } & \text { Easy to Use }\end{array}$ \\
\hline Visual Appeal & Representational Delight & $\begin{array}{ll}\text { - } & \text { Satisfaction of Visualty } \\
\text { - } & \text { Appealing Design } \\
\text { - } & \text { Interesting Layout }\end{array}$ \\
\hline
\end{tabular}


In conclusion application quality, consists of specific characteristics as formative measures. These are structural firmness, functional convenience, and representational delight. Examples used in literature that apply to these respective categories summarizes them as security, navigability, and visual appeal. As more detail, the security gives priority to privacy of customers' personal information, navigability focuses on applications interface and easiness of usage, as for the last one visual appeal is consists of visual attractiveness of applications. These three categories as a determinant has chosen because, they can reflect the multi-faceted nature of the applications quality (Wells, Parboteeah \& Valacich, 2011, p.39).

\section{Research Design and Methodology}

\subsection{Aim of the Research}

Before starting the research, a very question was asked in order to explain customers' impulsive behavior in mobile. The question was, what can directly affect the mobile impulsive behavior of a customer? After the question a comprehensive literature review has been made and a proposed research model has emerged. In this study, within some determinants chosen as an endogenous to the mobile impulsiveness scope of comparison between two third party application providers. Application used for the study were chosen for their features. Zubizu is claimed to be hedonic and Hopi is utilitarian consumption.

\subsection{Data Collection, Limitations and the Sample}

In order to collect the required data for the study, an online survey was conducted among Zubizu and Hopi users. In the questionnaire form there was an explanation of what this survey about and after explanation 40 questions (for details see appendix 1.) asked to participants for the impulsiveness, promotions and application's quality (all scale question asked in the form of five point Likert in which 1 is strongly disagree and 5 is strongly agree). After the scale questions 6 categorical questions were asked to determine participants' demographical situation.

As in all survey studies, there are some constraints in this study. Study is conducted with a limited time and a specific region in Turkey. Also due to the cost factor of study and availability of selected applications users, data collection is conducted with snowball sampling. Thus, in the end of data collection over 170 data were collected from respondents dated May 14 to 27 at 2018. In order to purify the research data were cleaned to 146 . Because of difficulty to reach the customers who use chosen applications and low population of chosen applications' user, data collection has stopped in given number. 


\subsection{Hypothesis}

After composing and integrating the literature and research question, a model proposes to measure the customers' mobile impulse buying behavior. In this research, for the proposed model there are two hypotheses;

$\mathrm{H}_{1}$ : Application quality effects mobile impulse buying behavior.

$\mathrm{H}_{2}$ : Mobile promotion effects mobile impulse buying behavior.
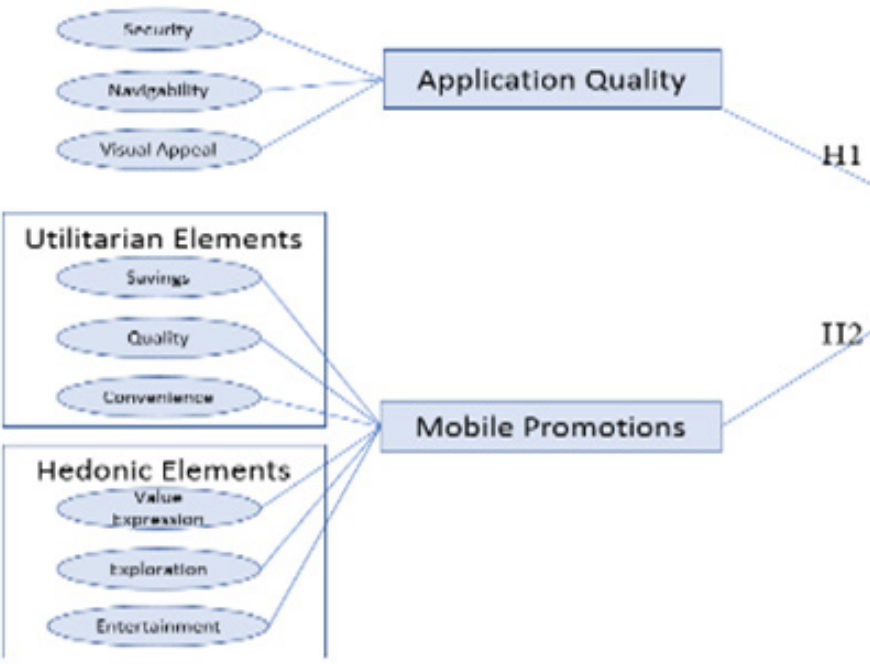

Mobile Promotions

Figure 2. Research Model

Source: Application Quality scale has taken from "Wells, Parboteeah \& Valacich, (2011). Online Impulse Buying: Understanding the Interplay between Consumer Impulsiveness and Website Quality" and adopted total of 14 items. Mobile Promotions scale has taken from "Chandon, Wansink \& Laurent (2000). A Benefit Congruency Framework of Sales Promotion Effectiveness" and adopted total of 21 items. Mobile Impulse Buying Behavior scale has taken from "Parboteeah, Valacich \& Wells, (2009). The Influence of Website Characteristics on a Consumer's Urge to Buy impulsively" and adopted total of 5 items (For more details, see Appendix 1).

\subsection{Research Findings}

\subsubsection{Demographical Findings}

The data obtained from the participants were tested via SPSS. According to the analysis of the data the demographic characteristics of the participants are summarized and given in "Table 2". 
Table 2. Demographical Distributions

\begin{tabular}{|c|c|c|c|}
\hline Variables & Group & Frequency & Valid Percent \\
\hline \multirow{3}{*}{ Gender } & Male & 48 & $32.9 \%$ \\
\hline & Female & 98 & $67.1 \%$ \\
\hline & Total & 146 & \\
\hline \multirow{3}{*}{ Marital Status } & Married & 75 & $51.4 \%$ \\
\hline & Single & 71 & $48.6 \%$ \\
\hline & Total & 146 & \\
\hline \multirow{4}{*}{ Age } & $18-24$ & 44 & $30.1 \%$ \\
\hline & $25-34$ & 67 & $45.9 \%$ \\
\hline & $35-44$ & 35 & $24.0 \%$ \\
\hline & Total & 146 & \\
\hline \multirow{4}{*}{ Graduate } & Below Bachelor & 11 & $7.50 \%$ \\
\hline & Bachelor & 78 & $53.4 \%$ \\
\hline & Above Bachelor & 57 & $39.0 \%$ \\
\hline & Total & 146 & \\
\hline \multirow{4}{*}{ Occupation } & Student & 55 & $37.7 \%$ \\
\hline & Private Sector & 72 & $49.3 \%$ \\
\hline & Public Sector & 19 & $13.0 \%$ \\
\hline & Total & 146 & \\
\hline \multirow{6}{*}{ Income Level } & $0-1000 \mathrm{TL}$ & 26 & $17.8 \%$ \\
\hline & $1001-2000 \mathrm{TL}$ & 17 & $11.6 \%$ \\
\hline & $2001-3000 \mathrm{TL}$ & 2 & $1.40 \%$ \\
\hline & $3001-4000 \mathrm{TL}$ & 53 & $36.3 \%$ \\
\hline & $4001 \mathrm{TL}$ and above & 48 & $32.9 \%$ \\
\hline & Total & 146 & \\
\hline
\end{tabular}

Total Zubizu Users $=62(42.5 \%)$

Total Hopi Users= 84 (57.5\%)

According to the "Table 2" in the selected sample of 146 participants, $33 \%$ of the participants consisted of male and $67 \%$ of female. For the second variable "marital status"; $48,6 \%$ of the participants consisted of single persons and $51.4 \%$ of are married persons. In the third variable "age" it's seen as most of the participants age ranges between 25 and 34 with almost 46\%. As for the fourth demographical variable "graduate", it's seen as over the half of the participants have bachelor degree graduate. In the occupation category participants distributed as $37.7 \%$ student, $49.3 \%$ private sector workers and $13 \%$ public sector workers. As for the last demographical variable "income level" subsequent to $4001 \mathrm{TL}$ and above (32.9\%) most of the participants earns in the range between 3001 and $4000 \mathrm{TL}$ with the percent of almost $\% 36$.

\subsubsection{Factor and Reliability}

In order to maximize the efficiency of the collected sample, a principle component factor analysis is applied to the data. Within this period of factor analysis, 3 principle component conducted for scales of the research. Factor analysis with varimax method required the deduction of some items 
because of the proximity of the same item to two factors and below average $(0,50)$ factor loadings (Durmuş, Yurtkoru \& Çinko, 2013). After completing the factor analysis, reliability analysis conducted for the left items. At the end of reliability analysis, all items left were in orderly put again in the factor analysis. In addition, Kaiser-Meyer-Olkin test of sampling adequacy for the factors were ranged from 0,643 to 0,870 and the all of the results were significant at the level of $\mathrm{p}=0,000$ in the Bartlett's Test of Sphericity. These results actually mean, the sample chosen is adequate for the conduction of analysis and is significant.

After all these necessary steps upon the proposed model, results of the factor analysis and reliability tests are summarized. In conclusion, table 3 demonstrates summary of all factor analysis and figure 3 displays revised research model (For more details see App.2-3-4).

Table 3. Summary of Factor Analysis

\begin{tabular}{llll}
\hline Factor Name & \# of Items & $\boldsymbol{\alpha}$ & Total Var. Exp. (\%) \\
\hline Application Quality & 5 & .939 & 35.893 \\
\hline Navigability & 3 & .963 & 20.117 \\
\hline Security & 3 & .872 & 15.187 \\
\hline Visual Appeal & 3 & .762 & 11.236 \\
\hline Mobile Impulse Buying Behavior & 3 & .892 & 54.399 \\
\hline Recommendation Based Buying Behavior & 2 & .947 & 33.296 \\
\hline Utilitarian Elements & 6 & .949 & 47.552 \\
\hline Hedonic Elements & 6 & .951 & 12.557 \\
\hline Quality & 3 & .939 & 9.059 \\
\hline Exploration & 3 & .838 & 8.195 \\
\hline Mobile Promotions & 3 & .944 & 7.120 \\
\hline
\end{tabular}

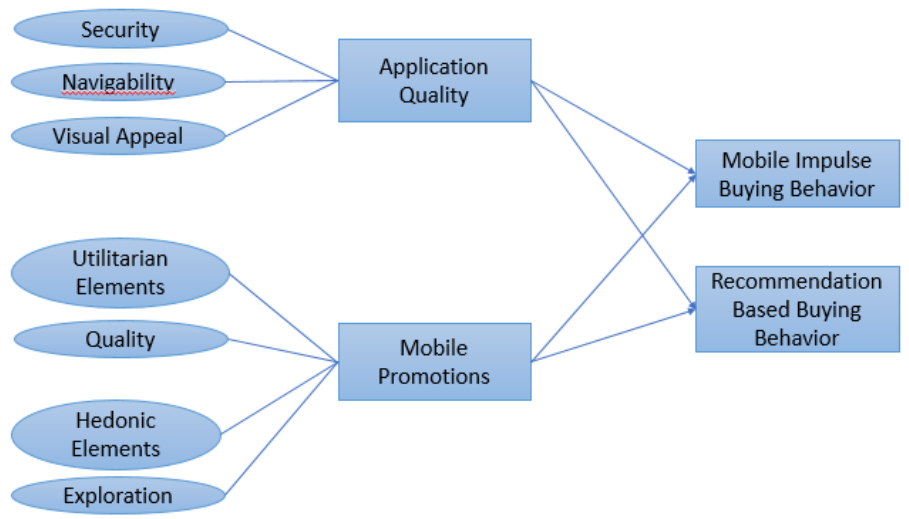

Figure 3. Revised Research Model after Factor Analysis 


\subsubsection{Results}

After the factor analysis a multiple regression analysis is conducted. During the regression analysis as the model proposed, "mobile impulse buying behavior" and "recommendation based buying behavior" are chosen as dependent variables and 2 independent variables "application quality" and "mobile promotions" has chosen. According to the model first independent was "application quality". This dimension has three factors under and named as shown in above figure 3. On the other "mobile promotions" dimension has four factors. According to this information multiple regression analysis is conducted for four times for each dimensions. As for the last information, under every dimension all independent variables are examined for multicollienarity. As a result, among the variance inflation factors (VIF) the largest value was 1,996. That means since the VIF value is below the level 10, multicollienarity does not causes any problem for this research (Hair Jr., et al., 2010).

Table 4. Summary of Regression Analysis

\begin{tabular}{|c|c|c|c|c|c|c|c|}
\hline Independent & $\rightarrow$ & Dependent & $\beta$ & $\mathrm{t}$ & Sig. & Tolerance & VIF \\
\hline Security & $\rightarrow$ & Application Quality & -.110 & -1.439 & .152 & .984 & 1.016 \\
\hline Navigability & $\rightarrow$ & Application Quality & .182 & 2.330 & .021 & .939 & 1.065 \\
\hline Visual Appeal & $\rightarrow$ & Application Quality & .353 & 4.532 & .000 & .944 & 1.059 \\
\hline Util. Elements & $\rightarrow$ & Mobile Promotions & .207 & 2.065 & .041 & .508 & 1.967 \\
\hline Quality & $\rightarrow$ & Mobile Promotions & .015 & .196 & .845 & .903 & 1.108 \\
\hline Hed. Elements & $\rightarrow$ & Mobile Promotions & .275 & 2.722 & .007 & .501 & 1.996 \\
\hline Exploration & $\rightarrow$ & Mobile Promotions & .140 & 1.695 & .092 & .752 & 1.330 \\
\hline App. Quality & $\rightarrow$ & MIBB & -.037 & -.460 & .646 & .935 & 1.070 \\
\hline M. Promotions & $\rightarrow$ & MIBB & .406 & 5.111 & .000 & .935 & 1.070 \\
\hline App. Quality & $\rightarrow$ & RBBB & .173 & 2.206 & .029 & .935 & 1.070 \\
\hline M. Promotions & $\rightarrow$ & $\mathrm{RBBB}$ & .345 & 4.410 & .000 & .935 & 1.070 \\
\hline
\end{tabular}

In the first regression analysis for the "application quality", following findings are extracted. The results indicate that, in "application quality" dimension $\mathrm{R}^{2}$ of the model is approximately $19 \%$ in the significance level 0,000 which means independent variables nearly explains 19\% of the variation of dependent variable. After model summary, coefficient table of regression analysis has examined. According to that, two of the independent variables effects the dependent variable under a significant level below 0,05. The first independent variable in "application quality" as coded "security" has no influence on the dependent variable ( $p>0,05)$. Second independent "navigability", positively influences at the approximate level of $18 \%(\mathrm{p}<0,05)$. Third, the "visual appeal" positively influences at the approximate level of $35 \%(\mathrm{p}<0,05)$.

Table 5. Regression Analysis for Application Quality

Dependent Variable: Application Quality

Independent Variables $\beta$

B t

t

Sig.

Tolerance

VIF 


\begin{tabular}{llllll}
\hline Security & -.110 & -1.439 & .152 & .984 & $\mathbf{1 . 0 1 6}$ \\
\hline Navigability & .182 & 2.330 & $\mathbf{. 0 2 1}$ & .939 & $\mathbf{1 . 0 6 5}$ \\
\hline Visual Appeal & .353 & 4.532 & $\mathbf{. 0 0 0}$ & .944 & $\mathbf{1 . 0 5 9}$ \\
\hline
\end{tabular}

Model Summary: $\mathrm{R}^{2}=.188$

ANOVA: $F=10.963 \mathrm{Sig}=.000$

In the second regression analysis for the "mobile promotions" following findings are extracted. The results indicate that, $\mathrm{R}^{2}$ of the model is approximately $28 \%$ in the significance level 0,000 , which means in the model the four independent variables nearly explain $28 \%$ of the variation of dependent variable. After model summary, again coefficient table of regression analysis has examined. According to that, two of the independent variables effects the dependent variable under a significant level below 0,05. The first independent variable "utilitarian elements" positively influences the "mobile promotions" at the approximate level of $21 \%(\mathrm{p}<0,05)$. Second, "hedonic elements" positively influences at the approximate level of $28 \%(\mathrm{p}<0,05)$.

Table 6. Regression Analysis for Mobile Promotions

\begin{tabular}{llllll}
\hline Dependent Variable: Mobile Promotions & & & & & \\
\hline Independent Variables & $\boldsymbol{\beta}$ & $\mathbf{t}$ & Sig. & Tolerance & VIF \\
\hline Utilitarian Elements & .207 & 2.065 & $\mathbf{. 0 4 1}$ & .508 & 1.967 \\
\hline Quality & .015 & .196 & .845 & .903 & 1.108 \\
\hline Hedonic Elements & .275 & 2.722 & .007 & .501 & 1.996 \\
\hline Exploration & .140 & 1.695 & .092 & .752 & 1.330 \\
\hline Model Summary: $\mathbf{R}^{2}=. \mathbf{2 8 0}$ & & & & & \\
ANOVA: $\mathrm{F}=\mathbf{1 3 . 6 7 6}$ Sig=.000 & & & & & \\
\hline
\end{tabular}

Third regression analysis for the "mobile impulse buying behavior", model summary indicate that independent variables nearly explains $16 \%$ of the variation of the dependent with the significance level 0,000. According to this information, coefficient table indicates that; “application quality" doesn't affect "mobile impulse buying behavior $\left(\mathrm{H}_{1}\right.$ rejected), on the other hand with the significance level below 0,05 "mobile promotions" effect impulsiveness with approximate level of $.41 \%\left(\mathrm{H}_{2}\right.$ accepted).

Table 7. Regression Analysis for Mobile Impulse Buying Behavior

\begin{tabular}{llllll}
\hline Dependent Variable: Mobile Impulse Buying Behavior & & & & & \\
\hline Independent Variables & $\boldsymbol{\beta}$ & $\mathbf{t}$ & Sig. & Tolerance & VIF \\
\hline Application Quality & -.037 & -.460 & .646 & .935 & 1.070 \\
\hline Mobile Promotions & .406 & 5.111 & .000 & .935 & 1.070 \\
\hline $\begin{array}{l}\text { Model Summary: } \mathbf{R}^{2}=\mathbf{. 1 5 8} \\
\text { ANOVA: F=13.443 Sig=.000 }\end{array}$ & & & & & \\
\hline
\end{tabular}


In the last regression analysis "recommendation based buying behavior", model summary results indicate that independent variables nearly explains $18 \%$ of the variation of the dependent with the significance level 0,000. After last model summary, coefficient table indicates that; all independent variables in this model positively effects the dependent variable with the significance level below 0,05 . According to all these given information, as shown in appendix 8 the first independent variable called "application quality" positively influences at the approximate level of $17 \%\left(\mathrm{H}_{3}\right.$ accepted). Second independent variable called as "mobile promotions" also positively influences at the approximate level of $35 \%$ ( $\mathrm{H}_{4}$ accepted). As a result, all of the findings given at the figure 4 .

Table 8. Regression Analysis for Recommendation Based Buying Behavior

\begin{tabular}{llllll}
\hline Dependent Variable: Recommendation Based Buying Behavior & & & & & \\
\hline Independent Variables & $\boldsymbol{\beta}$ & $\mathbf{t}$ & Sig. & Tolerance & VIF \\
\hline Application Quality & .173 & 2.206 & $\mathbf{. 0 2 9}$ & .935 & 1.070 \\
\hline Mobile Promotions & .345 & 4.410 & $\mathbf{. 0 0 0}$ & .935 & 1.070 \\
\hline Model Summary: $\mathbf{R}^{2}=.180$ & & & & & \\
ANOVA: F=15.662 Sig=.000 & & & & & \\
\hline
\end{tabular}

As a result, all data gathered from regression analysis' is shown figure below. According to the Figure 4 . 3 elements, 1 from application quality and 2 from mobile promotions have p value above 0,05 . Thus these 3 elements' regression value's does not need to be shown in the figure. Besides, in the application quality it's seen as in total visual appeal affects more than navigability and in mobile promotions hedonic elements were slightly above from utilitarian's. On the other hand, MIBB and RBBB mostly affected by mobile promotions.

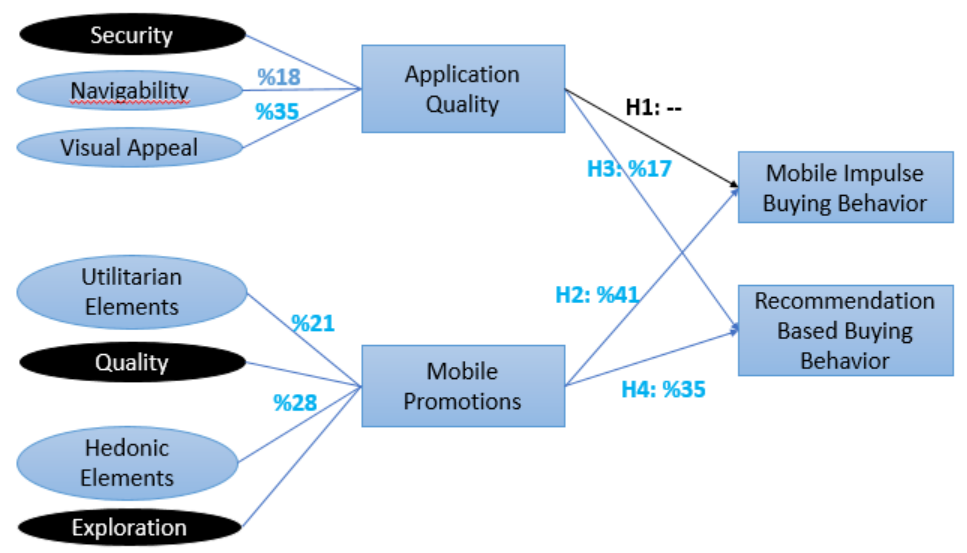

Figure 4. Summary of Regression Analysis 


\subsubsection{Differences Between Zubizu \& Hopi Applications}

In order to find the differences between Zubizu and Hopi, two distinct methods was used. First, Zubizu and Hopi users' responds examined in the way of average mean differences between them (shown in figure 5). Second, according to the accepted hypothesis a path analysis conducted in order to find regression differences between Zubizu and Hopi (shown in figure 6).

\section{Mean Differences Between Zubizu \& Hopi}

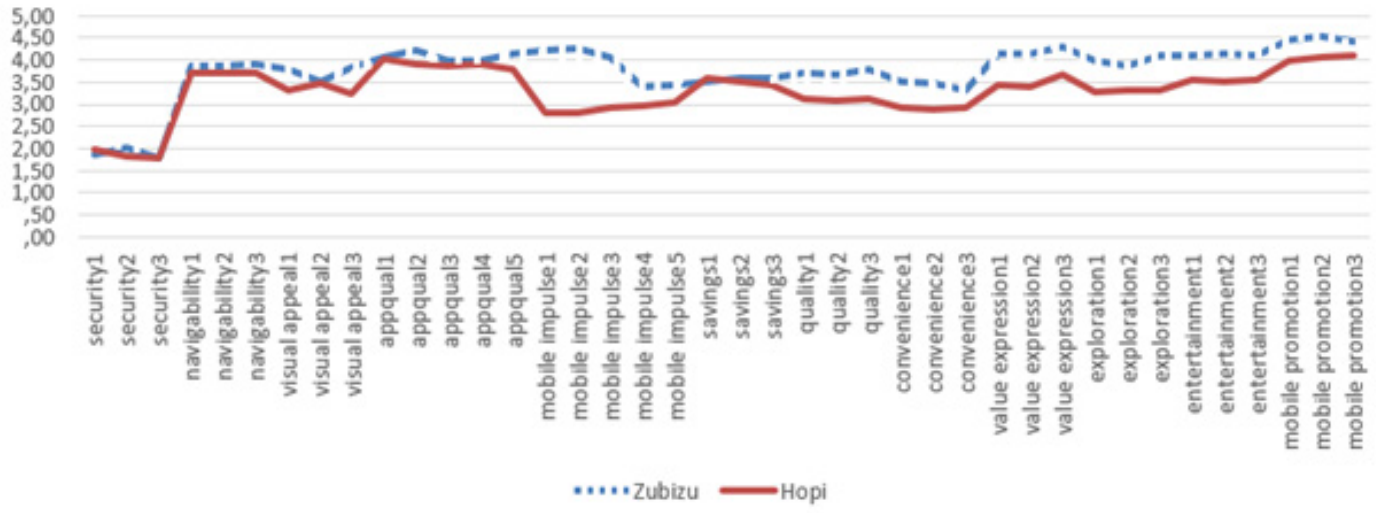

Figure 5. Average Mean Differences Between Zubizu \& Hopi

According to the figure 5; when application quality's and its dimensions' average mean for Zubizu and Hopi has examined, it's seen as there is only little differences among them. On the other hand, where first 3 questions of mobile impulsiveness coded as "mobile impulse buying behavior" there is a huge gap between Zubizu and Hopi. (Zubizu users average mean $>4$, Hopi users'<3). In the last two questions of mobile impulsiveness (which indicates recommendation based buying behavior) gap closes but still there is an average mean of 0,5 points with Zubizu above Hopi.

Secondly, in the mobile promotion dimensions as for the utilitarian elements means of "savings" seems nearby but, in "quality" and "convenience" again Zubizu has the upper hand against Hopi $\left(\mu_{z}>\right.$ $\mu_{\mathrm{m}}$ approximate difference 0,5 ). This upper hand of average mean for Zubizu continues for the mobile promotions and hedonic elements such as; value expression, exploration and entertainment. 


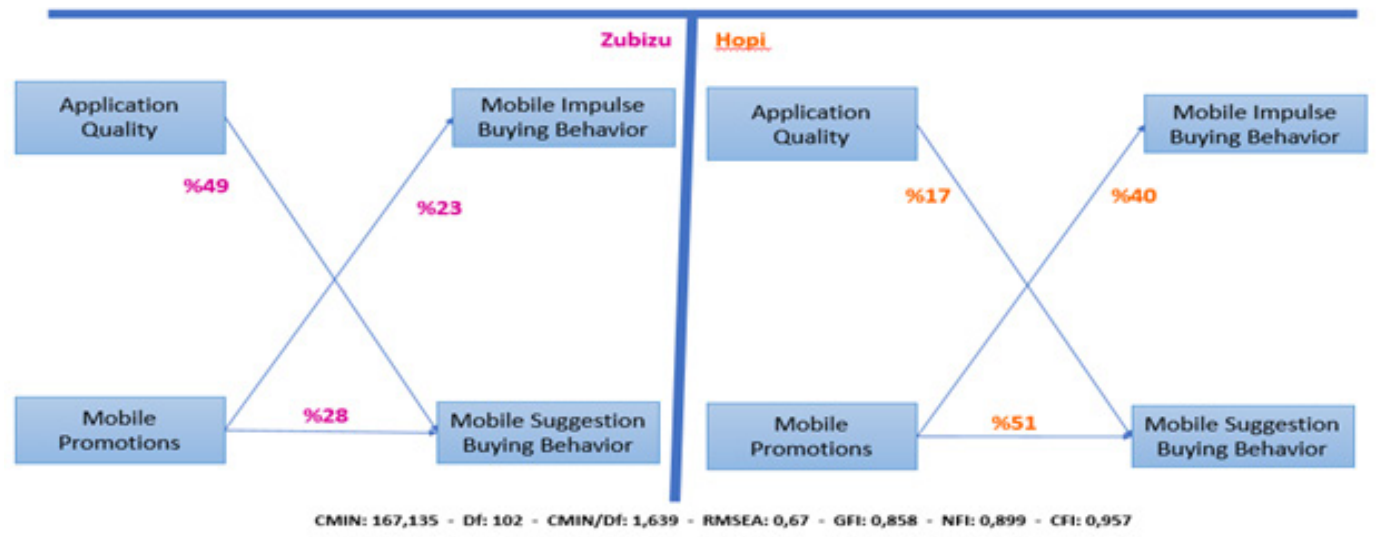

Figure 6. Regression Differences Between Zubizu \& Hopi

According to the path analysis conducted in AMOS v.22, (all indices show that path acquires the least requirements) in the "application quality" Zubizu's quality affects recommendation based buying behavior more than Hopi's. The reason of this is most probably in the Zubizu there are customized suggestions for its users. On the other hand, in "mobile promotions" Hopi's promotions are much more effective in compare to Zubizu's in the way of "mobile impulsive buying behavior" and "recommendation based buying behavior". Main reason for this, could be Hopi gives more promotions than Zubizu.

\section{Conclusion}

In this research, main purpose was to evaluate the impulsiveness of customers via applications. For this purpose; first impulsive buying behavior scale was adopted for the mobile applications. Thorough extensive literature research, subsequent to two important factors that affect impulsiveness has found, thus the research model has developed (See for details Appendix 1.). After model improvement, according to the factor analysis and reliability test scores the model has slightly changed (Figure 3.).

Secondary purpose of this research was to compare differences between two applications, Zubizu and Hopi. With two approaches first comparing mean differences, second path analysis (with only accepted hypothesis), the differences among them has been analyzed (respectively figure 5. and 6.).

In the results for main purpose of this research following interpretations can be made;

- Application quality mostly attributed by visual appeal, afterwards navigability. This means, as much as customers care about navigability of applications within the scope of quality, they care much more for visual appeal of applications. 
- When mobile promotions analyzed, savings and convenience united as utilitarian perspective, value expression and entertainment united as hedonic. Therefore, in one hand, mobile promotions can be affected by hedonic elements and on the other hand by utilitarian's. Also the weight of this elements for mobile promotions were close to each other. In short, as Chandon and others mentions in 2000, result means mobile promotions carry hedonic elements as well as utilitarian's.

- According to the factor analysis, mobile impulsiveness has split to two dimensions. In the literature review one of the conducted research by Liao, Shen \& Chu at 2009 buying impulsiveness is also examined with two dimensions as pure and reminder. First mobile impulsive buying behavior (mibb), second recommendation based buying behavior (rbbb). For $\mathrm{H}_{1}$ and $\mathrm{H}_{2}$, firstly dependent variable mibb has tested. According to the results, effect of application quality on mibb couldn't found within collected sample. Second, effect of mobile promotions on mibb is has examined and quite high effect of mobile promotions has resulted. This means, mobile customers impulsively buy things affected by not applications quality but mobile promotions.

- For $\mathrm{H}_{3}$ and $\mathrm{H}_{4}$, effect of application quality and mobile promotions on rbbb has examined. This time, application quality has effected the rbbb but in compare with the effect of mobile promotions it was almost the half size. This means, suggestions thorough applications can be ended as buying behavior when its represented with application quality but can be more persuasive when its presented with mobile promotions. This results are similar with some other researches. Such as; Liao, Shen \& Chu at 2009 showed that when comparing utilitarian and hedonic purchases within a given promotion, utilitarian purchase is more effective than hedonic. Palazn-Vidal \& Delgado-Ballester (2005), Andrew and others 2016 mentions promotions affects not only normal purchases but also directly affects impulsive purchases. On the other hand, as in this study Eroglu (2001), mentions application quality plays an important role on impulsive buying. This argument can be extended with Parboteeah, Valacich \& Wells, 2009, application quality can influence impulsive buying. In this research results show similarities with previous researches. In addition, shows that application quality is more important for hedonic consumptions.

Secondary purpose of this research was to explore difference between Zubizu and Hopi. According to this purpose first average means of responses has examined for both, second a path analysis conducted for each. In conclusion, following interpretations can be made;

- When average mean differences have examined, it's clearly shown except applications quality and utilitarian elements of mobile promotions in almost every aspect, Zubizu's average was way above Hopi's. Therefore, the most important gap is in the mobile promotions. When it's observed Zubuzi has seen as mostly hedonic. In conclusion both application provides the same application quality and almost same utilitarian elements but Zubizu provides much 
more hedonic elements for represented promotions. That's why the gap between them opens wide and becomes huge in the mobile impulsiveness. In very short, users of Zubizu's more impulsive because of hedonic reasons such as entertainment and value expression.

- According to the conducted path analysis, it's seen as Zubizu's quality is more effective than Hopi's in the way of rbbb. This means, applications must be customized options for users in order to effect the suggestive buying behavior.

- On the other hand, when effect of mobile promotions on mibb was examined, Hopi's promotions were much more effective in compare to Zubizu's. It means giving more promotions as Hopi does, can be more effective for customers' impulsive buying.

Besides from this results, as a notion for all the studies, this study also has its own limitations. Such as; the research is conducted within a limited time, data is gathered online from mostly students and limited because of difficulty in reaching Zubizu and Hopi users. As for further studies; within this research each scale was adopted for mobile shopping (Webqual to Appqual, Online Promotions to Mobile Promotions and Impulsive Buying Behavior to MIBB) because of lack of scales for mobile shopping. Researchers can test this scale for other mobile applications in order to reach a very reliability.

\section{REFERENCES}

Agarwal, R., \& Venkatesh, V. (2002). Assessing a firm's web presence: a heuristic evaluation procedure for the measurement of usability. Information Systems Research, 13(2), 168-186.

Agrebi, S., \& Jallais, J. (2015). Explain the intention to use smart phones for mobile shopping. Journal of Retailing and Consumer Services, 16, 16-23.

Akram, U., Hui, P., Kaleem Khan, M., Tanveer, Y., Mehmood, K., \& Ahmad, W. (2018). How website quality affects online impulse buying: Moderating effects of sales promotion and credit card use. Asia Pacific Journal of Marketing and Logistics, 30(1), 235-256.

Alba, J., Lynch, J., Witz, V., Janiszewski, C., Lutz, R., Sawyer, A., \& Wood, S. (1997). Interactive home shopping: consumer, retailer, and manufacturer incentives to participate in electronic marketplaces. The Journal of Marketing, 61(3), 38-53.

Andrews, M., Goehring, J., Hui, S., Pancras, J., \& Thornswood, L. (2016). Mobile promotions: A framework and research priorities. Journal of Interactive Marketing, 34, 15-24.

Apple Insider. (2017, January 30). Retrieved from https://appleinsider.com/articles/17/01/30/starbucks-voicerecognition-barista-beta-starts-on-iphone-prior-to-wide-summer-rollout.

BBC News Services. (2017, November 11). Retrieved from https://www.bbc.com/news/world-asiachina-41954591.

Boschetti, R. I., Perin, M. G., Barcellos, M. D., Sampaio, C. H., \& Basso, K. (2017). Non-monetary sales promotion effects on credit cards. Journal of Financial Services Marketing, 22(1), 3-13.

Buil, I., De Chernatony, L., \& Martinez, E. (2013). Examining the role of advertising and sales promotions in brand equity creation. Journal of Business Research, 66(1), 115-122. 
Business Wire. (2017, November 11). Retrieved from https://www.businesswire.com/news/ home/201.710.19005594/en/Alibaba-Group-Launches-2017-11.11-Global-Shopping.

Campbell, L., \& Diamond, W. D. (1990). Framing and sales Promotions: The characteristics of a "Good Deal". Journal of Consumer Marketing, 7(4), 25-31.

Carter, B. (2017, November 15). Blog access development. Retrieved from https://blog.accessdevelopment.com/ ultimate-collection-coupon-statistics.

Chandon, P., Wansink, B., \& Laurent, G. (2000). A benefit congruency framework of sales promotion effectiveness. Journal of marketing, 64(4), 65-81.

Chandran, S., \& Morwitz, V. G. (2006). The price of "free"-dom: Consumer sensitivity to promotions with negative contextual influences. Journal of Consumer Research, 33(3), 384-392.

Durmuş, B., Yurtkoru, E. S., \& Çinko, M. (2013). Sosyal bilimlerde SPSS'le veri analizi. İstanbul: Beta Yayınları.

Eroglu, S. A., Machleit, K. A., \& Davis, L. M. (2003). Empirical testing of a model of online store atmospherics and shopper responses. Psychology \& marketing, 20(2), 139-150.

Eroglu, S., Machleit, K. A., \& Davis, L. M. (2001). Atmospheric qualities of online retailing: A conceptual model and implications. Journal of Business research, 54(2), 177-184.

Fang, Z., Gu, B., Luo, X., \& Xu, Y. (2015). Contemporaneous and delayed sales impact of location-based mobile promotions. Information Systems Research, 26(3), 552-564.

Floh, A., \& Madlberger, M. (2013). The role of atmospheric cues in online impulse-buying behavior. Electronic Commerce Research and Applications, 12(6), 425-439.

Forbes. (2019). Retrieved from https://www.forbes.com/sites/sergeiklebnikov/2019/11/11/alibabas-1111singles-day-by-the-numbers-a-record-38-billion-haul/\#7f15fb512772.

Forrester Research Inc. (2014). The state of digital coupons: How digital coupons are adapting to mobile and omnichannel. A Forrester Consulting Thought Leadership Paper.

Girardello, A., \& Michahelles, F. (2010). Explicit and implicit ratings for mobile applications. GI Jahrestagung, $1,606-612$.

Hail, S. H., Hand, D. J., Sigmon, S. C., Badger, G. J., Meyer, M. C., \& Higins, S. T. (2016). Using behavioral economic theory to increase use of effective contraceptives among opioid-maintained women at risk of unintended pregnancy. Preventive medicine, 92, 62-97.

Hair Jr., J. F., Black, W. C., Babin, B. J., \& Anderson, R. E. (2010). Multivariate data analysis. (7th Edition). New Jersey: Prentice Hall.

Haubl, G., \& Trifts, V. (2000). Consumer decision making in online shopping environments: The effects of interactive decision aids. Marketing Science, 19(1), 4-21

Hung, M. C., Yang, S. T., \& Hsieh, T. C. (2012). An examination of the determinants of mobile shopping continuance. International Journal of Electronic Business Management, 10(1), 29-37.

Internet World Stats. (2019). Retrieved from https://www.internetworldstats.com/emarketing.htm.

Kim, S., \& Stoel, L. (2004). Apparel retailers: website quality dimensions and satisfaction. Journal of Retailing and Consumer Services, 11(2), 109-117.

Köksal, Y. (2014). The efficiency of monetary and non-monetary sales promotions on brand preference; a case of Albanian GSM companies. Istanbul University Journal of the School of Business, 43(2), 319-331.

Lee, Y., \& Kozar, K. A. (2006). Investigating the effect of website quality on e-business success: An analytic hierarchy process (AHP) approach. Decision support systems, 42(3), 1383-1401. 
Liao, S. L., Shen, Y. C., \& Chu, C. H. (2009). The effects of sales promotion strategy, product appeal and consumer traits on reminder impulse buying behaviour. International Journal of Consumer Studies, 33(3), 274-284.

Loiacono, E. T., Watson, R. T., \& Goodhue, D. L. (2007). WebQual: An instrument for consumer evaluation of web sites. International Journal of Electronic Commerce, 11(3), 51-87.

Loiacono, E., Chen, D., \& Goodhue, D. (2002). WebQual TM revisited: predicting the intent to reuse a Web site. AMCIS 2002 Proceedings, 46, 301-309.

Lu, H. P., \& Su, Y. J. (2009). Factors affecting purchase intention on mobile shopping web sites. Internet Research, 19(4), 442-458.

Mani, M., Kavanagh, D. J., Hides, L., \& Stoyanov, S. R. (2015). Review and evaluation of mindfulness-based iPhone apps. JMIR mHealth and uHealth, 3(3), 1-10. doi: 10.2196/mhealth.4328.

Miyazaki, A. D., \& Fernandez, A. (2001). Consumer perceptions of privacy and security risks for online shopping. Journal of Consumer affairs, 35(1), 27-44.

Palazn-Vidal, M., \& Delgado-Ballester, E. (2005). Sales promotions effects on consumer-based brand equity. International Journal of market research, 47(2), 179-204.

Parboteeah, D. V., Valacich, J. S., \& Wells, J. D. (2009). The influence of website characteristics on a consumer's urge to buy impulsively. Information systems research, 20(1), 60-78.

Rifkin, J. (2014). The zero marginal cost society: The internet of things, the collaborative commons, and the eclipse of capitalism. New York: St. Martin's Press.

Rook, D., \& Fisher, R. J. (1995). Normative influences on impulsive buying behavior. Journal of consumer research, 22(3), 305-313.

Scarpi, D. (2012). Work and fun on the internet: the effects of utilitarianism and hedonism online. Journal of interactive marketing, 26(1), 53-67.

Shankar, V., \& Balasubramanian, S. (2009). Mobile marketing: a synthesis and prognosis. Journal of interactive marketing, 23(2), 118-129.

Shankar, V., Venkatesh, A., Hofacker, C., \& Naik, P. (2010). Mobile marketing in the retailing environment: current insights and future research avenues. Journal of interactive marketing, 24(2), 111-120.

Siau, K., \& Shen, Z. (2003). Mobile communications and mobile services. International Journal of Mobile Communications, 1(1-2), 3-14.

Statcounter. (2016, November 1). Retrieved from http://gs.statcounter.com/press/mobile-and-tablet-internetusage-exceeds-desktop-for-first-time-worldwide

Statista. (2017). The Statistics Portal. Retrieved from https://www.statista.com/statistics/276623/number-ofapps-available-in-leading-app-stores/

Stoyanov, S. R., Hides, L., Kavanagh, D. J., \& Wilson, H. (2016). Development and validation of the user version of the mobile application rating scale (uMARS). JMIR mHealth and uHealth, 4(2), 1-5.

Stoyanov, S. R., Hides, L., Kavanagh, D. J., Zelenko, O., Tjondronegoro, D., \& Mani, M. (2015). Mobile app rating scale: a new tool for assessing the quality of health mobile apps. JMIR mHealth and uHealth, 3(1), 1-9.

Verhagen, T., \& Van Dolen, W. (2011). The influence of online store beliefs on consumer online impulse buying: A model and empirical application. Information \& Management, 48(8), 320-327.

Ward, M. R. (2001). Will online shopping compete more with traditional retailing or catalog shopping?. Netnomics, 3(2), 103-117. 
Webrazzi. (2018, April 17). Retrieved from https://webrazzi.com/2018/04/17/pgnin-gencleri-hedefleyenbanabak-uygulamasinin-detaylari-paylasildi/

Wells, J. D., Parboteeah, V., \& Valacich, J. S. (2011). Online impulse buying: understanding the interplay between consumer impulsiveness and website quality. Journal of the Association for Information Systems, 12(1), $32-56$.

Wolfinbarger, M., \& Gilly, M. C. (2001). Shopping online for freedom, control, and fun. California Management Review, 43(2), 34-55.

Yan, B., \& Chen, G. (2011). AppJoy: personalized mobile application discovery. Proceedings of the 9th international conference on Mobile systems, applications, and services, June 2011. pp.113-126. doi: 10.1145/1999.995.2000007.

Yang, K. (2012). Consumer technology traits in determining mobile shopping adoption: An application of the extended theory of planned behavior. Journal of Retailing and Consumer Services, 19(5), 484-491.

Zhou, L., Dai, L., \& Zhang, D. (2007). Online shopping acceptance model-A critical survey of consumer factors in online shopping. Journal of Electronic commerce research, 8 (1), 41-62. 


\section{APPENDIX}

App 1. Detailed Proposed Model

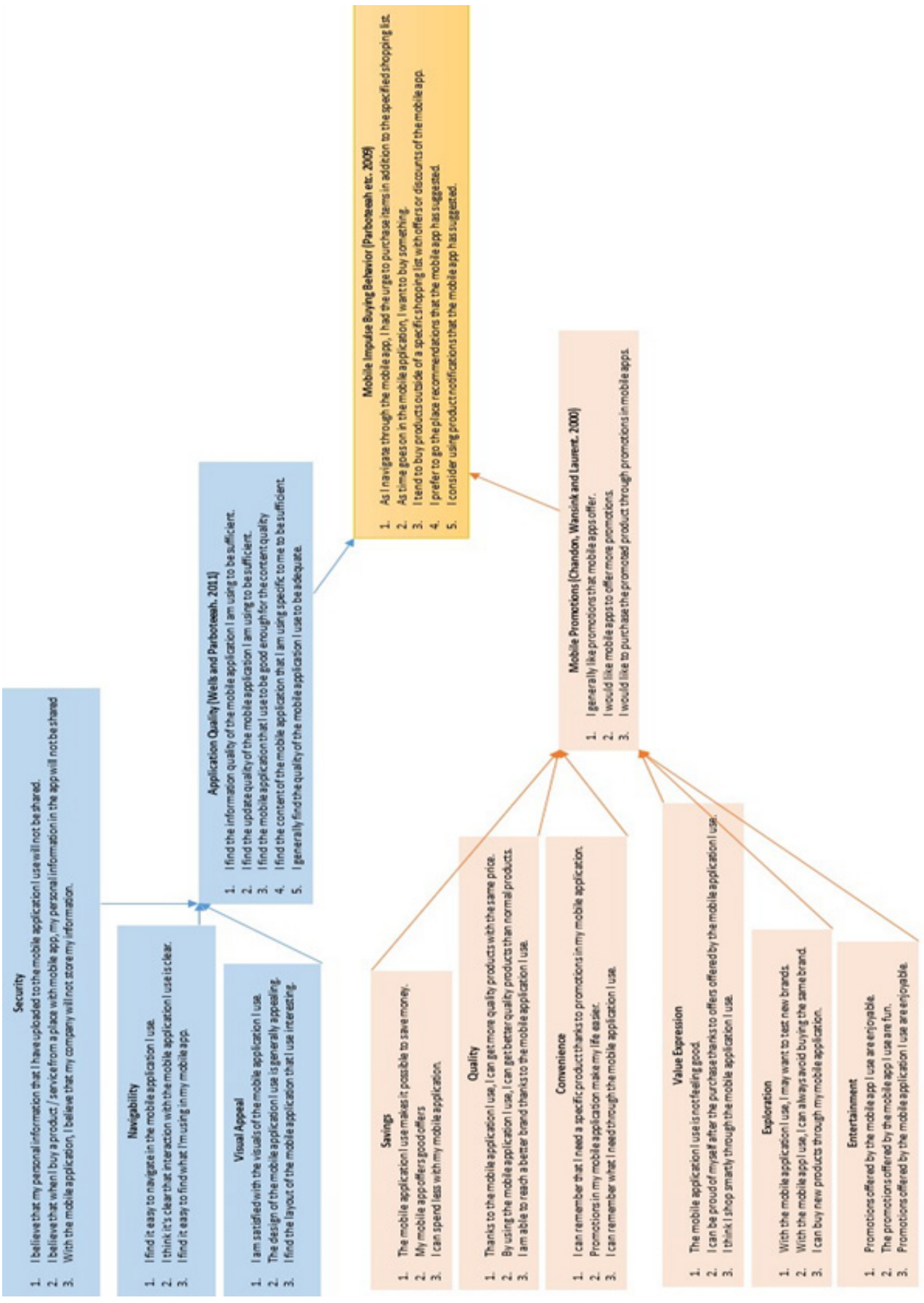


App 2. Factor \& Reliability for Application Quality

\begin{tabular}{|c|c|c|c|c|}
\hline Factor Name & Items & Factor Loadings & $a$ & Total Var. Exp. (\%) \\
\hline \multirow{5}{*}{ Application Quality } & Appqual3 & .936 & \multirow{5}{*}{.939} & \multirow{5}{*}{35.893} \\
\hline & Appqual4 & .935 & & \\
\hline & Appquall & .906 & & \\
\hline & Appqual2 & .823 & & \\
\hline & Appqual5 & .780 & & \\
\hline \multirow{3}{*}{ Navigability } & Navil & .964 & \multirow{3}{*}{.963} & \multirow{3}{*}{20.117} \\
\hline & Navi2 & .962 & & \\
\hline & Navi3 & .917 & & \\
\hline \multirow{3}{*}{ Security } & Sec1 & .907 & \multirow{3}{*}{.872} & \multirow{3}{*}{15.187} \\
\hline & Sec3 & .886 & & \\
\hline & Sec2 & .876 & & \\
\hline \multirow{3}{*}{ Visual Appeal } & Vis2 & .851 & \multirow{3}{*}{.762} & \multirow{3}{*}{11.236} \\
\hline & Vis3 & .804 & & \\
\hline & Vis1 & .787 & & \\
\hline \multicolumn{4}{|l|}{ Total } & 82.433 \\
\hline \multicolumn{4}{|c|}{ Kaiser-Meyer-Olkin Measure of Sampling Adequacy } & .798 \\
\hline \multirow{3}{*}{\multicolumn{3}{|c|}{ Bartlett's Test of Sphericity }} & Approx Chi-Square & 1780.114 \\
\hline & & & df & 91 \\
\hline & & & Sig. & .000 \\
\hline
\end{tabular}

App 3. Factor \& Reliability for Mobile Impulse Buying Behavior

\begin{tabular}{|c|c|c|c|c|c|}
\hline \multicolumn{2}{|l|}{ Factor Name } & Items & Factor Loadings & $\alpha$ & Total Var. Exp. (\%) \\
\hline \multirow{3}{*}{$\begin{array}{l}\text { Mobile Impulse } \\
\text { Behavior }\end{array}$} & \multirow{3}{*}{ Buying } & Impluse1 & .932 & \multirow{3}{*}{.892} & \multirow{3}{*}{54.399} \\
\hline & & Impluse3 & .903 & & \\
\hline & & Impluse2 & .876 & & \\
\hline \multirow{2}{*}{$\begin{array}{l}\text { Recommendation } \\
\text { Buying Behavior }\end{array}$} & \multirow{2}{*}{ Based } & Impluse 5 & .971 & \multirow{2}{*}{.947} & \multirow{2}{*}{33.296} \\
\hline & & Impluse4 & .967 & & \\
\hline \multicolumn{5}{|l|}{ Total } & 87.695 \\
\hline \multicolumn{5}{|c|}{ Kaiser-Meyer-Olkin Measure of Sampling Adequacy } & .643 \\
\hline \multirow{3}{*}{\multicolumn{4}{|c|}{ Bartlett's Test of Sphericity }} & Approx Chi-Square & 511.076 \\
\hline & & & & df & 10 \\
\hline & & & & Sig. & .000 \\
\hline
\end{tabular}


App 4. Factor \& Reliability for Mobile Promotions

\begin{tabular}{|c|c|c|c|c|}
\hline Factor Name & Items & Factor Loadings & $a$ & Total Var. Exp. (\%) \\
\hline \multirow{6}{*}{ Utilitarian Elements } & Savings3 & .871 & \multirow{6}{*}{.949} & \multirow{6}{*}{47.552} \\
\hline & Convenience3 & .858 & & \\
\hline & Convenience2 & .851 & & \\
\hline & Conveniencel & .850 & & \\
\hline & Savings1 & .746 & & \\
\hline & Savings2 & .658 & & \\
\hline \multirow{6}{*}{ Hedonic Elements } & Entertainment3 & .857 & \multirow{6}{*}{.951} & \multirow{6}{*}{12.557} \\
\hline & Entertainment2 & .851 & & \\
\hline & Entertainment1 & .832 & & \\
\hline & V-Expression3 & .763 & & \\
\hline & V-Expression1 & .708 & & \\
\hline & V-Expression2 & .704 & & \\
\hline \multirow{3}{*}{ Quality } & Quality2 & .959 & \multirow{3}{*}{.939} & \multirow{3}{*}{9.059} \\
\hline & Quality1 & .941 & & \\
\hline & Quality3 & .882 & & \\
\hline \multirow{3}{*}{ Exploration } & Exploration1 & .854 & \multirow{3}{*}{, 838} & \multirow{3}{*}{8.195} \\
\hline & Exploration2 & .798 & & \\
\hline & Exploration3 & .758 & & \\
\hline \multirow{3}{*}{ Mobile Promotions } & M-Promo2 & .905 & \multirow{3}{*}{.944} & \multirow{3}{*}{7.120} \\
\hline & M-Promo3 & .899 & & \\
\hline & M-Promo1 & .866 & & \\
\hline \multicolumn{4}{|c|}{ Total } & 84.483 \\
\hline \multicolumn{4}{|c|}{ Kaiser-Meyer-Olkin Measure of Sampling Adequacy } & .870 \\
\hline \multirow{3}{*}{\multicolumn{3}{|c|}{ Bartlett's Test of Sphericity }} & $\begin{array}{l}\text { Approx Chi- } \\
\text { Square }\end{array}$ & 4192.163 \\
\hline & & & $\mathrm{df}$ & 210 \\
\hline & & & Sig. & .000 \\
\hline
\end{tabular}

App 5. Regression Weights for Zubizu

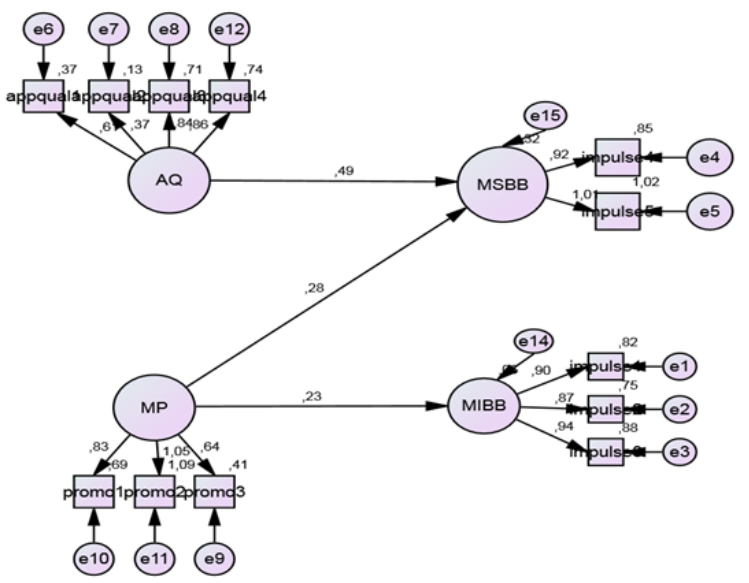


App 6. Regression Weights for Hopi

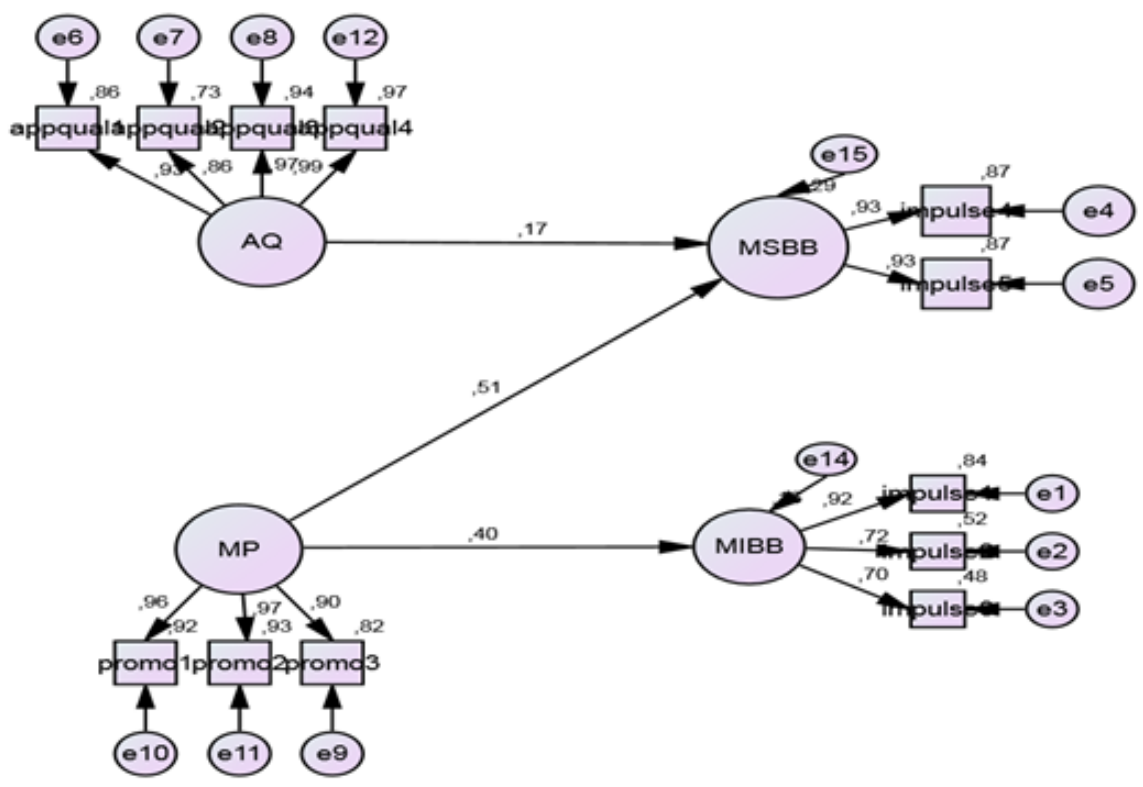

